\title{
Single nucleotide polymorphisms of follicle-stimulating hormone receptor promoter and their impacts to the promoter activities
}

\author{
Yuni Ahda ${ }^{*}$, Jörg Gromoll $^{f}$, Purnomo Soeharso ${ }^{\neq}$, Septelia Inawati Wanandi ${ }^{\S}$, Nukman Moeloek ${ }^{\ddagger}$
}

\begin{abstract}
Abstrak
Respon wanita usia reproduksi bervariasi terhadap stimulasi FSH eksogen. Salah satu penyebab variasi tersebut adalah perbedaan genotip akibat adanya polimorfisme pada ekson 10 gen reseptor FSH. Untuk mengetahui lebih lanjut apakah daerah promotor inti gen reseptor FSH juga polimorfik dan apakah polimorfisme tersebut mempengaruhi aktivitas promotor, dilakukan skrining polimorfisme promotor gen reseptor FSH pada 262 wanita yang mengikuti program IVF/ICSI, diikuti uji fungsional untuk mengetahui pengaruh polimorfisme terhadap aktivitas promotor. Hasil penelitian menunjukkan bahwa daerah promotor inti gen reseptor FSH polimorfik. Ditemukan lima SNPs pada posisi -29, -37, -114, -123 dan-138 di samping ditemukannya variasi jumlah basa adenin. Polimorfisme pada posisi -123 menurunkan aktivitas promotor secara bermakna, sebaliknya polimorfisme pada posisi -37 dan -138 meningkatkan aktivitas promotor secara bermakna, sedangkan polimorfisme pada posisi -29, -114 dan pemendekan basa adenin tidak mempengaruhi aktivitas promotor secara bermakna. Perbedaan aktivitas promotor akibat polimorfisme ini pada akhirnya sangat memungkinkan merubah sensitivitas ovarium terhadap FSH. (Med J Indones 2004; 13: 205-14)
\end{abstract}

\begin{abstract}
Women of reproductive ages are varies in their responses to exogenous FSH stimulations. The difference of FSHR genotype due to the polymorphisms in exon 10 is one of its significant factors. To know further whether the core promoter of FSHR is also polymorphic and to know whether those polymorphisms influence the promoter activity, we did polymorphism screening of FSHR promoter to 262 women undergoing IVF/ICSI, followed by functional study to know the impact of polymorphisms to the promoter activity. This study indicated that the core promoter of human FSHR is polymorphic. We found five SNPs at positions $-29,-37,-114,-123$ and -138 in addition to the variety number of adenines. Polymorphism at position -123 significantly decreased the promoter activity, in contrast, polymorphism at position -37 and -138 significantly increased the promoter activity, whereas polymorphism at position -29, -114 and short adenines stretch did not significantly influence the promoter activity. The differences of the promoter activities due to polymorphisms might change the ovarian sensitivity to FSH. (Med J Indones 2004; 13: 205-14)
\end{abstract}

Keywords: core promoter of human FSH receptor, single nucleotide polymorphisms, FSHR gene.

Follicle-stimulating hormone (FSH) is one of the important sex hormones in the male and female reproductive system and required for the development of germ cells. FSH induces spermatogenesis and oogenesis through the interaction with a specific receptor localized exclusively in Sertoli cells of testis and granulosa cells of ovary. ${ }^{1,2}$

\footnotetext{
Biomedical Postgraduate Program, Faculty of Medicine, University of Indonesia, Jakarta, Indonesia

${ }^{f}$ Institute of Reproductive Medicine, University of Muenster, Germany

* Department of Medical Biology, Faculty of Medicine, University of Indonesia, Jakarta, Indonesia

$\S$ Department of Biochemistry and Molecular Biology, Faculty of Medicine, University of Indonesia, Jakarta, Indonesia
}

The FSH receptor protein is encoded by the FSH receptor gene which consists of 10 exons and 9 introns. $^{2}$ Mutational screening of the FSH receptor gene showed two polymorphisms within exon 10 at amino acid positions 307 and 680 . These polymorphic forms produce two allelic variants: Thr307/Asn680 and Ala307/Ser680. ${ }^{3}$ Further studies showed that the polymorphism in exon 10 of FSH receptor gene influence the receptor protein conformation and thereby affects the ovarian sensitivity to FSH induction in women undergoing assisted reproduction program. ${ }^{4-6}$ In women undergoing IVF/ICSI, low dose of FSH could not achieve ovulation while hyperstimulation could cause serious complications, such as ovarian enlargement and extravasation of fluid to abdominal cavity leading to ascites, hypovolemia, and 
hemoconcentration. ${ }^{5-7}$ Therefore, it is necessary to determine the FSH receptor genotype of women undergoing assisted reproduction program in consideration that each woman has a specific tolerance to FSH due to her FSH receptor genotype.

Since the FSH receptor genotypes determination is important to predict the exact dose of FSH for stimulation, additional information on the biology of the FSH receptor gene is of clinical important. We hypothesized that besides the two single nucleotide polymorphisms (SNPs) in the coding sequence of FSH receptor gene, additional alterations could exist in its regulatory sequence. Indeed, from the preliminary study we found a tendency that the first 231 nucleotides of the 5'-flanking sequence of the FSHR gene are polymorphic. Therefore, in the present study we screened the polymorphisms in the promoter of human FSHR in larger samples and did functional study to know whether SNPs in the core promoter influence the promoter activity. This study is of benefit to know whether polymorphism in the promoter also contribute to ovarian sensitivity to FSH induction.

\section{METHODS}

\section{Detection of human FSHR promoter SNPs using PCR-SSCP-sequencing and TaqMan technology}

This study was conducted at Institute of Reproductive Medicine (IRM), University Clinics of Muenster Germany. Two hundred and sixty two German women undergoing IVF/ICSI were recruited in this study. Polymorphisms screening of FSHR core promoter ${ }^{8}$ of 60 samples were done using PCR-SSCP-sequencing. However, the extension detection of polymorphism at position -29 of core promoter to another 202 samples were carried out by TaqMan technology. For PCR, two pairs of primer were used. The first pair, covered nucleotides -1 to -231 , was used for polymorphism screening, while the PCR product produced by the second pair of primer (nucleotides -7 to -221 ), was used for functional study. Both of primer pairs were listed at Table 1. Genomic DNA ( $500 \mathrm{ng})$ was amplified in a total reaction volume of $50 \mu$, containing $1.25 \mathrm{U}$ Taq polymerase (Promega), $200 \mu \mathrm{M}$ of each deoxynucleotide triphosphates, 20 pmol both forward and reverse primers and buffer containing $10 \mathrm{mM}$ Tris$\mathrm{HCl} \mathrm{pH} 9,50 \mathrm{mM} \mathrm{KCl}, 0.1 \%$ Triton X-100, $1.5 \mathrm{mM}$ $\mathrm{MgCl}$. Thirty five PCR cycles were performed as follows: denaturation $\left(94^{\circ} \mathrm{C}, 1 \mathrm{~min}\right)$, annealing $\left(56^{\circ} \mathrm{C}\right.$, $40 \mathrm{sec})$ and extension $\left(72^{\circ} \mathrm{C}, 1.5 \mathrm{~min}\right)$. PCR products were then denaturated at $95^{\circ} \mathrm{C}$ for 5 minutes after mixed them with $95 \%$ formamide, $10 \mathrm{mM}$ EDTA, 5\% glycerol, $0.01 \%$ xylene xyanole. The denatured PCR products were run in 20\% SSCP (polyacrilamide) gel (Invitrogen) for 4 hours. Finally, the DNA bands were visualized by silver nitric staining. Sequencing was done to confirm polymorphisms that were detected in SSCP gel. PCR primers were used as sequencing primers with the dideoxy chain termination method.

Table 1. Primers used for PCR

\begin{tabular}{cc}
\hline $\begin{array}{c}\text { Type of } \\
\text { primers }\end{array}$ & \multicolumn{1}{c}{ Sequence of primers } \\
\hline P1 & 5'-TATTCCAGACATGCCTAATGG-3' \\
P2 & 5'-CCAGCAAAGAGACCAGGAGC-3' \\
P3 & 5'-GGTCAGGGTGTAAGAAACCC-3' \\
P4 & 5'-GCATCCATCCACCTGATTTC-3' \\
\hline
\end{tabular}

Using TaqMan machine (ABI Prism 7000 sequence detection system, Applied Biosystems, USA) polymorphisms screening were done in two PCR steps, i.e.: absolute quantification and allelic discrimination. For absolute quantification, the cycles are as follows: Stage 1: $50^{\circ} \mathrm{C}, 2$ min $(1$ cycle) for probe binding; Stage 2: denaturation at $95^{\circ} \mathrm{C}, 10 \mathrm{~min}$ (1 cycle); and followed by 35 cycles at $95^{\circ} \mathrm{C}$ for $15 \mathrm{~s}$, and $60^{\circ} \mathrm{C}$ for $1 \mathrm{~min}$ (Stage 3), whereas allelic discrimination assay took 1 minute at $60^{\circ} \mathrm{C}$. Each PCR reaction $(25 \mu \mathrm{l})$ contained $2 \mu \mathrm{L}$ DEPC treated water, $12.5 \mu \mathrm{L}$ Universal master mix, $0.25 \mu \mathrm{L}$ of each probe, and $4.5 \mu \mathrm{L}$ of each primer ( $5 \mathrm{pmol})$. The probes and primers that were used in the PCR reactions are listed in Table 2 and Table 3, respectively. 
Table 2. Probes used for allelic discrimination applied TaqMan machine

\begin{tabular}{lll}
\hline \multicolumn{1}{c}{ Type of probes } & \multicolumn{1}{c}{ Sequence of probes } & \multicolumn{1}{c}{ Type of fluorescence } \\
\hline $680-\mathrm{G}$ & 5'-AGAGTCACCAgTGGTT-3' & (FAM fluorescence) \\
$680-\mathrm{A}$ & 5'-AGTCACCAaTGGTTC-3' & (VIC fluorescence) \\
307-G & 5'-TTATATGACTCAGgCTAGG-3' & (VIC fluorescence) \\
$307-A$ & 5'-ATTATATGACTCAGaCTAGG-3' & (FAM fluorescence) \\
$-29-G$ & 5'-TGCAAATGCAGgAAG-3' & (FAM fluorescence) \\
$-29-A$ & 5'-TGCAAATGCAGaAAG-3' & (VIC fluorescence) \\
\hline
\end{tabular}

Table 3. Primers used for allelic discrimination applied TaqMan machine

\begin{tabular}{ll}
\hline $\begin{array}{c}\text { Type of } \\
\text { primers }\end{array}$ & \multicolumn{1}{c}{ Sequence of primers } \\
\hline 680 forward & 5'-AAGGAATGGCCACTGCTCTTC-3' \\
680 reverse & 5'-GGGCTAAATGACTTAGAGGGACAA-3' \\
307 forward & 5'-CTTCATCCAATT TGCAACAAATCTAT-3' \\
307 reverse & 5'-TGTCTTCTGCCAGAGAGGATCTC-3' \\
-29 forward & 5'-AGCTTCTGAGATCTGTGGAGGTTT-3' \\
-29 reverse & 5'-AATTATGCATCCATC CA CCTGATT-3' \\
\hline
\end{tabular}

\section{Functional study of FSHR promoter}

\section{Plasmid preparation}

The 215 bp ( -221 to -7$)$ promoter regions containing each of five different SNPs, one short adenine sequences (13 As) and the wild type DNA sequence, amplified by PCR, were purified by electrophoresis on agarose gel and with Qiagen Agarose Gel Extraction kit. Initially, these 215 bp promoter regions of human FSHR gene were inserted to pCR 2.1 TOPO vector (Invitrogen), and then subcloned into the promotorless firefly luciferase reporter (pGL3) vector (Promega). The presence of each SNPs in the inserted segments and the direction of the inserted segments were verified with sequencing.

\section{Cell cultures, transient transfection and luciferase assay}

To study the basal activities of the wt- and polymorphic promoter constructs, the COS-7, SK-11, and JC-410 cell lines were cultured in Dulbecco's modified Eagle's medium (DMEM; Gibco BRL) with $4.5 \%$ glucose, $10 \%$ heat-inactivated fetal calf serum (FCS; Gibco BRL), penicillin (50 x $10^{3} \mathrm{U} / 1$; Biological industries), and streptomycin $(50 \mathrm{mg} / \mathrm{l}$; Biological industries) in a humidified $5 \% \mathrm{CO}_{2}$ incubator at $37^{\circ} \mathrm{C}$. The constructs $(2 \mu \mathrm{g})$ were transiently transfected into COS-7, SK-11, and JC-410 cell lines using $2 \mu \mathrm{l}(4 \mu \mathrm{g})$ lipofectamin (Invitrogen). Before transfections (18 24 hours) the cells were seeded onto six-well plates at 100.000 cells $/$ well. $^{9}$ Cells were cotransfected with 1 $\mu \mathrm{g}$ the internal control plasmid, $\mathrm{pRL}$ vector carrying Renilla luciferase reporter gene (Promega). Forty eight hours after starting the transfection, cells were washed with phosphate-buffered saline (PBS, pH 7.5), harvested by passive lysis cells method using passive lysis buffer (PLB; Promega). After centrifugation at $5000 \mathrm{~g}\left(30 \mathrm{sec}, 4^{\circ} \mathrm{C}\right)$, supernatant was transferred to fresh microtubes for luciferase measurement. Firefly and Renilla luciferase activities were measured by means of Dual luciferase kit (Promega) and luminometer. Relative luciferase activities of polymorphism constructs represent the percentage of activity with respect to the activity of the wild type construct. Each activity represents the mean \pm SEM of total measurements.

\section{Nuclear extracts preparation for EMSA}

Nuclear extracts were prepared according to Xing and Sairam ${ }^{10}$ with several modifications. Human primary granulosa, JC-410, and SK-11 cells were harvested in $1 \mathrm{ml}$ ice-cold PBS and spun down for 10 seconds at $12.000 \mathrm{rpm}$ at $4^{\circ} \mathrm{C}$. The pellet was resuspended in buffer A $(10 \mathrm{mM}$ HEPES/KOH $\mathrm{pH} 7.9,1.5 \mathrm{mM}$ $\mathrm{MgCl} 2,10 \mathrm{mM} \mathrm{KCl}, 0.5 \mathrm{mM}$ DTT, $0.2 \mathrm{mM}$ PMSF) and incubated on ice for 10 minutes. After vortexing, cells were spun down for another 10 seconds at 
$12.000 \mathrm{rpm}, 4^{\circ} \mathrm{C}$. Cells were lysed on ice for 20 minutes in buffer $\mathrm{C}$ (20 mM HEPES/KOH pH 7.9, 1.5 $\mathrm{mM} \mathrm{MgCl} 2,420 \mathrm{mM} \mathrm{NaCl}, 0.2 \mathrm{mM}$ EDTA, 25\% glycerin, $0.5 \mathrm{mM}$ DTT, $0.2 \mathrm{mM}$ PMSF) and spun down for 2 minutes at $12.000 \mathrm{rpm}$ at $4^{\circ} \mathrm{C}$. Nuclear extracts were stored in aliquot at $-70^{\circ} \mathrm{C}$.

\section{Electrophoretic mobility shift assay (EMSA)}

The wt and mutated oligonucleotides (Table 4) were purchased from a German company. The electrophoretic mobility shift assays (EMSAs) were performed as described by Xing and Sairam. ${ }^{10}$ Briefly, double stranded oligonucleotides were labeled at 5 ' ends using T4 polynucleotide kinase and $\gamma-{ }^{32} \mathrm{P}$-ATP. Nuclear extracts $(10 \mu \mathrm{g})$ of human primary granulosa, JC-410 and SK-11 cells were incubated in $2 \mathrm{X}$ binding buffer $(40 \mathrm{mM}$ HEPES $\mathrm{pH} 7.9,10 \mathrm{mM} \mathrm{MgCl} 2,160$ $\mathrm{mM} \mathrm{KCl,} 1 \mathrm{mM}$ DTT, $1 \mathrm{mM}$ EDTA, 20\% Glycerol, and $600 \mu \mathrm{g} / \mathrm{ml} \mathrm{BSA}$ ) containing $1 \mu \mathrm{g} / \mu \mathrm{l}$ poly (dI-dC) and $1 \mathrm{pmol}$ of labeled DNA probe. After addition of the radiolabeled probe, the mixtures were incubated at room temperature for 30 minutes. Excess unlabelled DNA competitors $(100 \mathrm{pmol})$ were added 30 minutes before adding the radiolabeled DNA probe. The DNA-nuclear extract binding was analyzed using 5\% nondenaturing polyacrilamide gels in $1 \mathrm{X}$ TBE buffer (50 mM Tris-borate-EDTA, $\mathrm{pH} 8.0$ ). Gels were then dried and visualized by autoradiography.

Table 4. The wt and mutated oligonucleotides used for EMSA

\begin{tabular}{|c|c|}
\hline $\begin{array}{c}\text { Oligo- } \\
\text { nucleotides }\end{array}$ & Sequence of oligonucleotides \\
\hline$-29 w t$ & $\begin{array}{l}5^{\prime} \text {-CAAATGCAGGAAGAAATCAGGTGG-3' } \\
3^{\prime} \text {-GTTTACGTCCTTCTTTAGTCCACC-5' }\end{array}$ \\
\hline$-29 p o l y$ & $\begin{array}{l}\text { 5' -CAAATGCAGAAAGAAATCAGGTGG-3' } \\
\text { 3'-GTTTACGTCTTTCTTTAGTCCACC-5' }\end{array}$ \\
\hline$-37 w t$ & $\begin{array}{l}5^{\prime} \text {-GTTTTTCTCTGCAAATGCAGGAAG-3' } \\
3^{\prime} \text {-CAAAAAGAGACGTTTACGTCCTTC-5' }\end{array}$ \\
\hline$-37 p o l y$ & $\begin{array}{l}5^{\prime} \text {-GTTTTTCTCTGCGAATGCAGGAAG-3' } \\
3^{\prime} \text {-CAAAAAGAGACGCTTACGTCCTTC-5' }\end{array}$ \\
\hline$-114 w t$ & $\begin{array}{l}5^{\prime} \text {-TCACATGACCCTACCAGTTCTCAAGTC-3' } \\
3^{\prime} \text {-AGTGTACTGGGATGGTCAAGAGTTCAG-5' }\end{array}$ \\
\hline$-114 \mathrm{poly}$ & $\begin{array}{l}5^{\prime} \text {-TCACATGACCCCACCAGTTCTCAAGTC-3' } \\
3^{\prime} \text {-AGTGTACTGGGGTGGTCAAGAGTTCAG-5' }\end{array}$ \\
\hline$-123 w t$ & $\begin{array}{l}5^{\prime} \text {-CTTGGTGGGTCACATGACCCTACC-3' } \\
3^{\prime} \text {-GAACCACCCAGTGTACTGGGATGG-5' }\end{array}$ \\
\hline$-123 p o l y$ & $\begin{array}{l}5^{\prime} \text {-CTTGGTGGGTCGCATGACCCTACC-3' } \\
3^{\prime} \text {-GAACCACCCAGCGTACTGGGATGG-5' }\end{array}$ \\
\hline$-138 w t$ & $\begin{array}{l}5^{\prime} \text {-AAAAAGCATCCCTTGGTGGGTCAC-3' } \\
3^{\prime} \text {-TTTTTCGTAGGGAACCACCCAGTG-5' }\end{array}$ \\
\hline$-138 \mathrm{poly}$ & $\begin{array}{l}5^{\prime} \text {-AAAAAGCTTCCCTTGGTGGGTCAC-3' } \\
3^{\prime} \text {-TTTTTCGAAGGGAACCACCCAGTG-5' }\end{array}$ \\
\hline
\end{tabular}

\section{Statistical analysis}

Statistical analysis was performed by applying a commercially available software package (SPSS; SPSS Inc, Chicago, IL and Sigmastat version 2.03, Jandel, Erkrath, Germany). Data were analyzed for normal distribution. Normally distributed data were subjected to one-way analysis of variance. In contrast, non-normally distributed data were subjected to Kruskal-Wallis. P values $\leq 0.05$ were considered statistically significant. Chi-square analysis was applied to categorical data.

\section{RESULTS}

\section{Polymorphisms within the core promoter of human FSHR}

PCR-SSCP-sequencing and TaqMan analysis in the core promoter $(-1$ to -231$)$ of 60 German women yielded 5 SNPs at positions: $-138(\mathrm{~A} \rightarrow \mathrm{T}),-123$ $(\mathrm{A} \rightarrow \mathrm{G}),-114(\mathrm{~T} \rightarrow \mathrm{C}),-37(\mathrm{~A} \rightarrow \mathrm{G})$, and $-29(\mathrm{G} \rightarrow \mathrm{A})$ (Figure 1 and 2). The highest frequency of polymorphism was found at position $-29(31.17 \%)$ whereas the other four polymorphisms were found in low frequencies $(<5 \%)$. The extension detection of polymorphism at position -29 to another 202 German women produced the genotype distributions: $7.25 \%$ for homozygous AA, $30.92 \%$ for heterozygous $\mathrm{AG}$ and $61.83 \%$ for homozygous GG (wild type). In addition, we found the variety of adenine bases stretch in the core promoter of FSHR. The lowest adenine stretch was 10 bases while the highest As stretch was 17 bases.

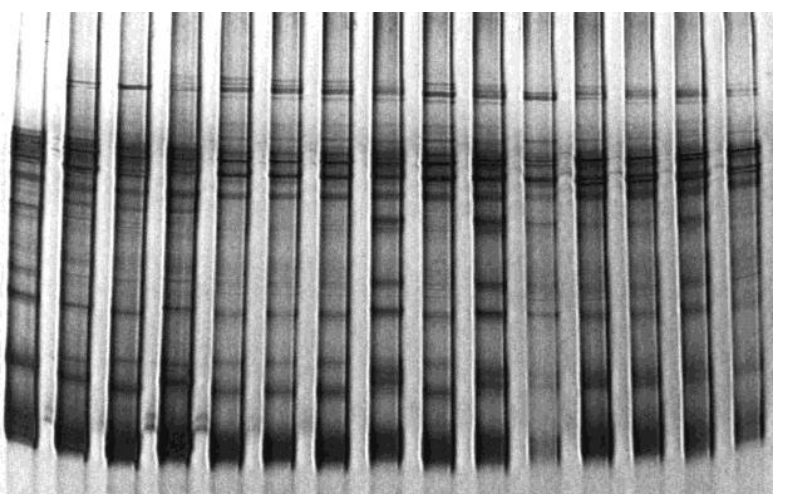

Figure 1. Representative SSCP gel that shows the aberration pattern of DNA migration (arrow) compared than wild type. Lane 1 is wild type, lane $2-4$ are markers. Lane $5-15$ are analyzed samples. 

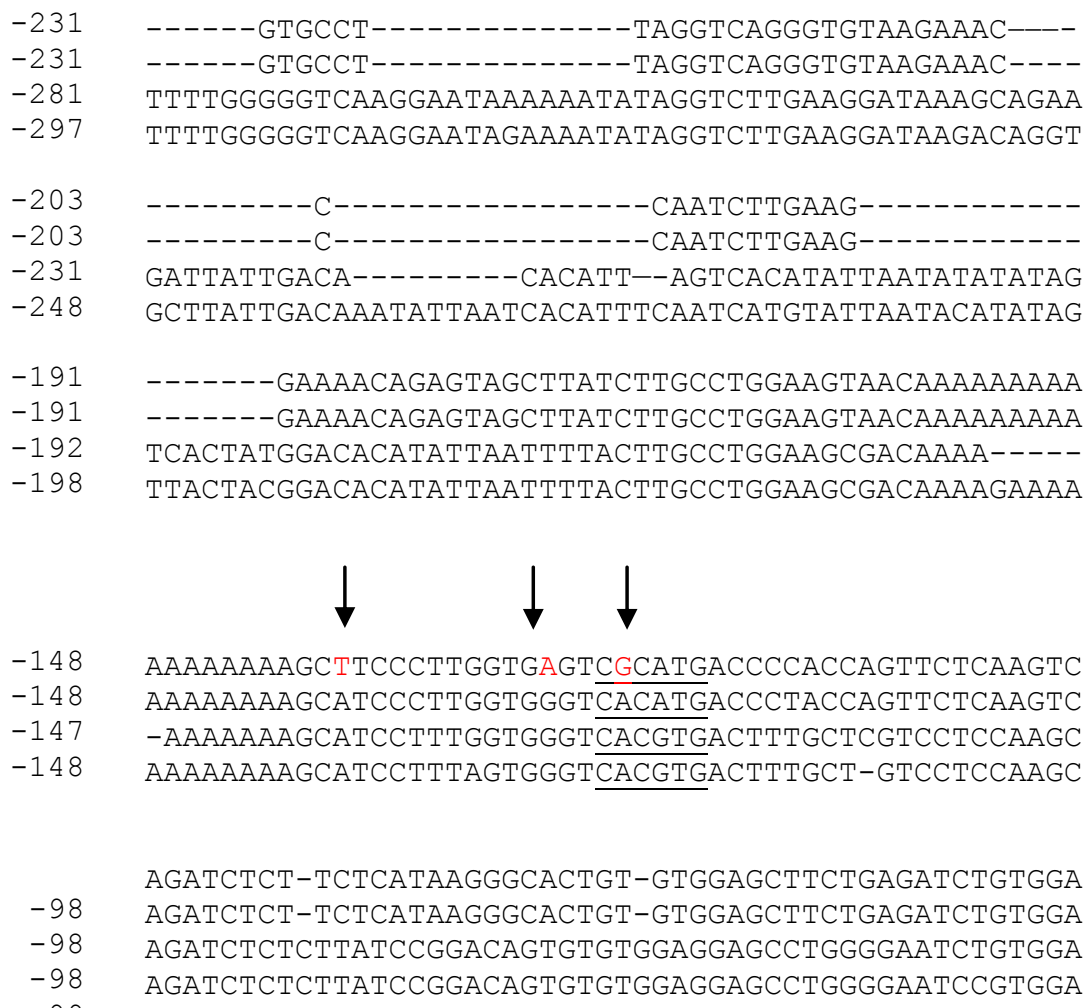

$-99$

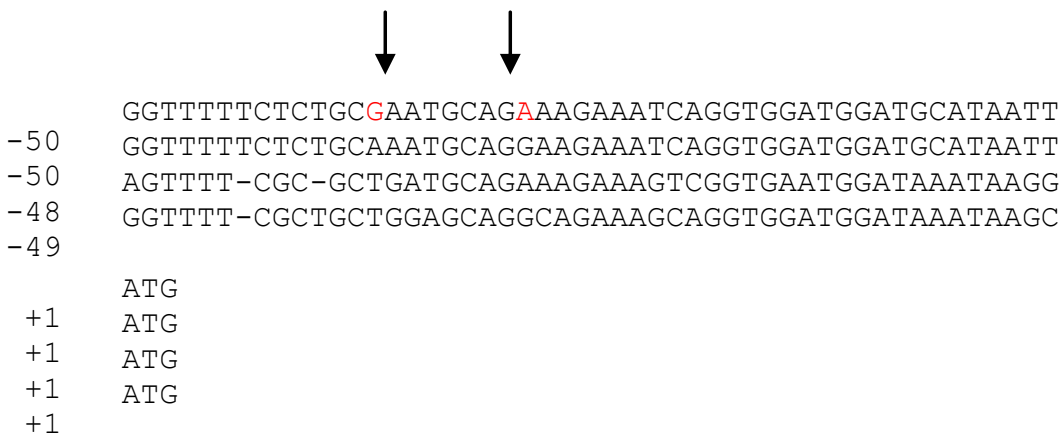

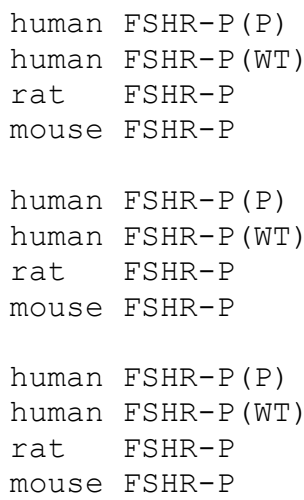

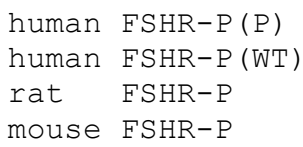

Figure 2. Alignment of the core promoter of FSH receptor sequences among species and five single nucleotide changes (arrow) were found in the core promoter of human FSHR as compared to the wild type sequence. E box sequences are underlined.

\section{Transient transfection studies (functional studies)}

To evaluate the contribution of each polymorphism on the promoter activity we created seven luciferase reporter/core promoter constructs represent each polymorphism found during FSHR promoter screening in women undergoing IVF/ICSI and the wild type sequence (Figure 3). Transient transfection study in the COS-7 cells showed the varying activities of luciferase/reporter gene constructs compared than wild type construct (Figure 4). The expressions of luciferase reporter genes were significantly higher when driven by promoter containing polymorphisms at position -37 and -138 compared than wild type. In contrast, the activity of the promoter was significantly decreased when containing polymorphism at position -123 , presented by low expression of luciferase reporter gene. Whereas two other polymorphisms (at position -29 and -114 ) and 13 adenines were not significantly decreased the promoter activities compared than wild type (Figure 4). 
To evaluate whether there are cell-specific factors involved on the FSHR expression, we continued this functional study by introducing constructs into the different cultured cells and measured the luciferase reporter gene expressions. The polymorphic promoters revealed the similar activities in JC-410 cells and SK-11 cells compared than COS-7 cells (Figure 4). Although the expression of luciferase reporter gene driven by promoter containing polymorphism at position -37 was lower in SK-11 and JC-410 cells compared than 138/promoter-construct, however, its expression was still significantly higher compared than wild type. These results indicated that there are no cell-specific transcription factors involved in the FSHR expression.

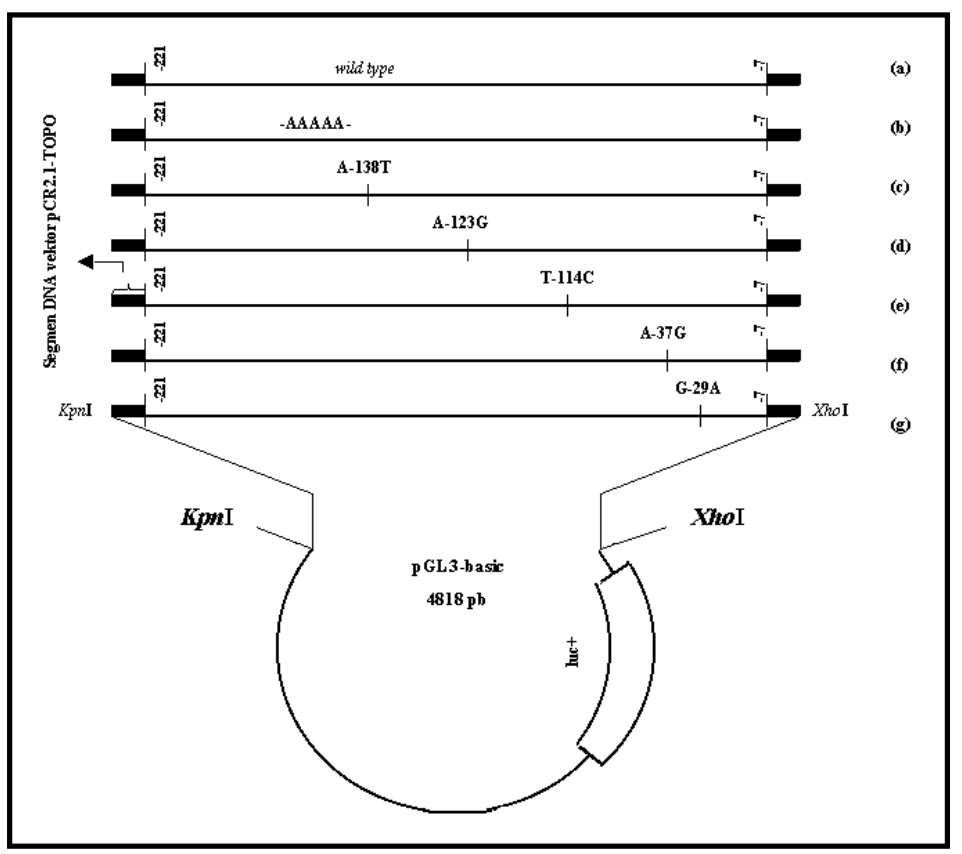

Figure 3. Luciferase/core promoter of FSHR constructs. (a) pGL3-basic/wild type construct, (b) pGL3-basic/13 poly As construct, (c) pGL3-basic/-138 construct, (d) pGL3-basic / 123 construct, (e) pGL3-basic/-114 construct, (f) pGL3-basic/-37 construct, (g) $p$ GL3-basic/-29 construct. These constructions were produced from the previous constructs (TOPO2.1/ core promoter). The black boxes are part of TOPO2.1 vector included in pGL3-basic/promoter constructs. KpnI and XhoI restriction enzymes were used to digest either $p G L 3$ vector or the inserted segments.

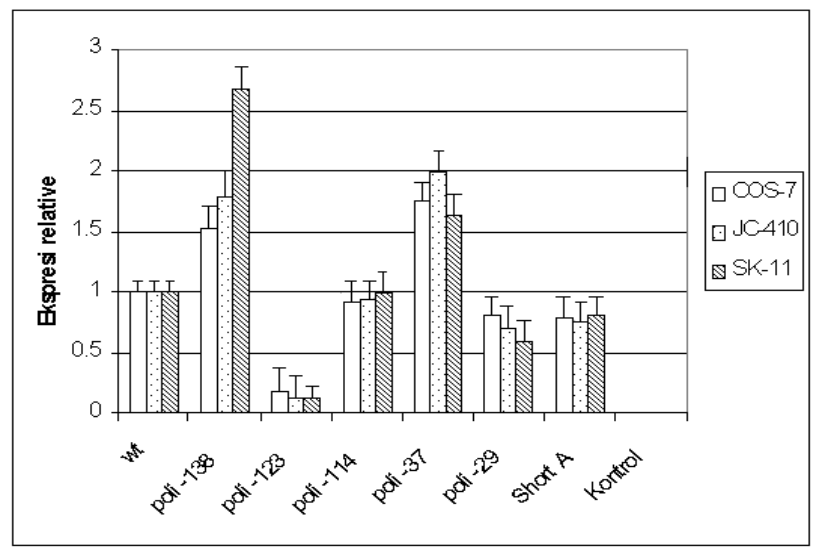

Figure 4. Relative expression (mean \pm SEM) of wt-and varian-promoter/luciferase constructs in COS-7, JC-410 and SK-11 cell lines. The expression of wt-promoter/luciferase construct is considered as $100 \%$. The relative expression of luciferase gen driven by promoters containing polymorphisms at position $-37,-123$ and -138 were significantly different than wild type construct ( $p \leq 0.05$, one way anova). 


\section{Effect of SNPs within the core promoter region on the binding capacity of transcription factors}

To know whether polymorphisms in the core promoter of human FSH receptor influence the binding capacity of transcription factor to its binding site, we did EMSA using nuclear proteins extracted from primary granulosa cells, SK-11 cells and JC-410 cell lines. The presence of either primary granulosa, SK-11 or JC-410 cell nuclear extracts in mutated 138-oligonucleotides produced specific DNA-protein complex as a smaller band that could not be detected in $-38 \mathrm{wt}$ oligonucleotide (Figure 5, lane 2, 7, 12). In contrast, mixture of those nuclear extracts and $-138 \mathrm{wt}$ oligonucleotides produced a specific DNA-protein complex with the slower migration in acrilamide gel (lane 1,6,11). These DNA-protein complex could be competed away by an excess of the unlabeled poly or wt oligonucleotides that indicating the specificity of the complexes. We suggest that polymorphism at position -138 of core promoter located in the binding site of transcription factor or suppressor protein, and this polymorphism increase the binding capacity of transcription factor or abolished the ability of suppressor protein to bind to its sites.

Experiment using -123 probes incubated with primary granulosa and SK-11 cell nuclear extracts produced a specific DNA-protein complex either in wild type or polymorphism probes. However, the -123-polyprobes produced the weaker signal (Figure 6, lane 2 and 7) than -123-wt-probes (lane 1 and 6). Using 100X excess competitors, all bands disappeared indicating the specificity of the DNA-protein complexes (lane 3, $4,8,9)$.

The specific DNA-protein complex could also be observed with EMSA when using the -29-poly probe. One prominent complex was observed when -29-poly probe incubated with either primary granulosa or SK11 nuclear extracts (Figure 7, lane 2 and 7), while this band did not appear in the -29-wt probe (lane 1 and 6). The DNA-protein complexes were competed with an excess of unlabeled -29-poly probe (lane 3, 4, 8, 9).
(A)

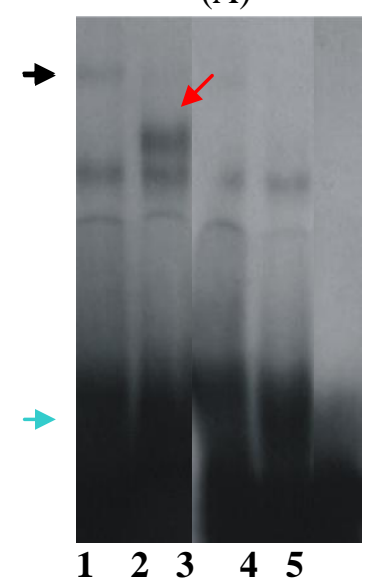

(B)

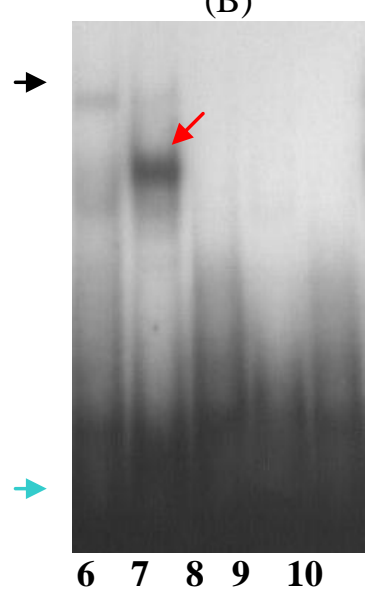

(C)

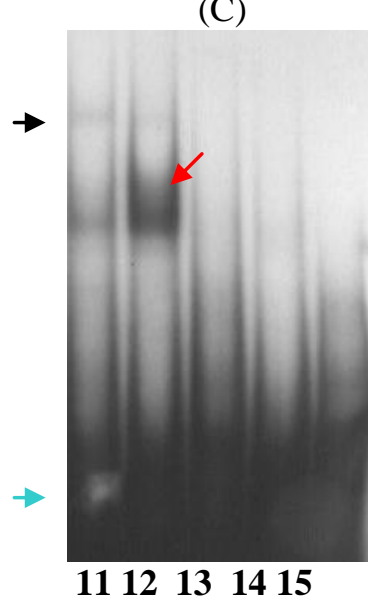

Figure 5. EMSA using primary granulosa (A), JC-410 (B) and SK-11 (C) cell nuclear extracts. The specific DNA-protein complexes could be detected either in-138-wt-or-138-poly-probe, however, they have different migration pattern. The-138-wt-probe has a bigger size band (lane 1, 6, 11, black arrow) whereas the -138-poly-probe has a smaller one (lane 2, 7, 12, red arrow). The bands were competed away by the excess of unlabelled oligonucleotides (lane 3, 4, 8, 9, 13, 14). Lane 5, 10, and 15 are negative control. Blue arrow indicated the free probes. 
(A)

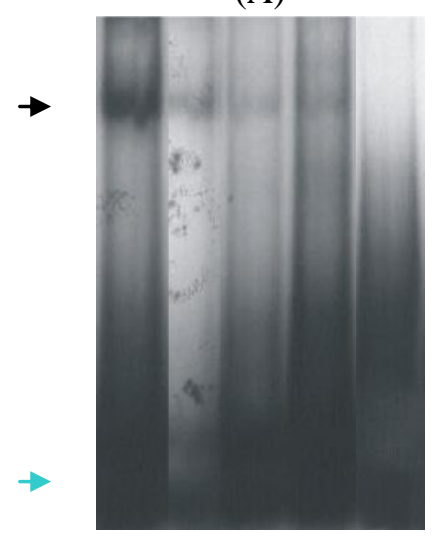

$\begin{array}{lllll}1 & 2 & 3 & 4 & 5\end{array}$
(B)

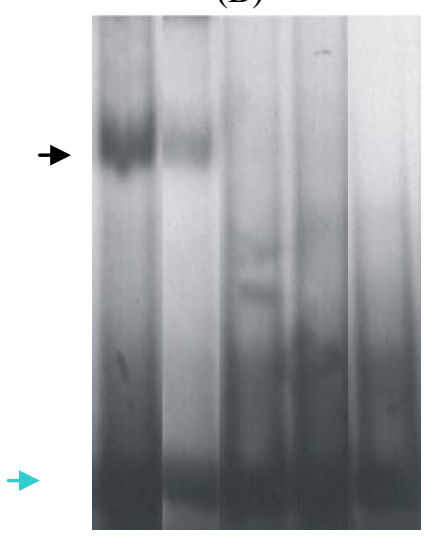

$\begin{array}{lllll}6 & 7 & 8 & 9 & 10\end{array}$

Figure 6. EMSA using primary granulosa $(A)$ and $S K-11(B)$ cell nuclear extracts. The specific DNA-protein complex was detected in-123-wt-probe with strong signals (lane 1 and 6) and become weak signal in-123-poly-probe (lane 2 and 7). The bands were competed away by the excess of unlabelled oligonucleotides (lane 3, 4, 8, 9). Lane 5 and 10 are negative control. Blue arrow indicated the free probes.

(A)

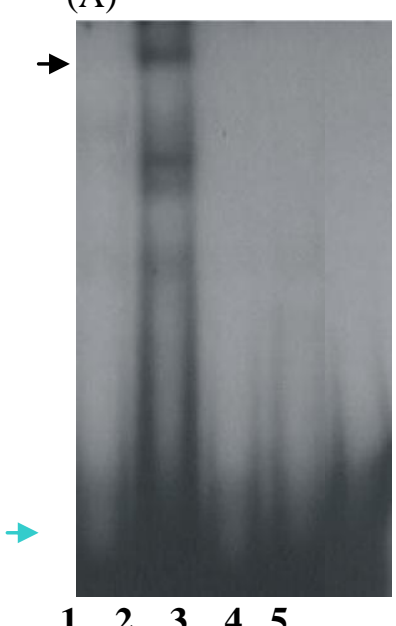

(B)

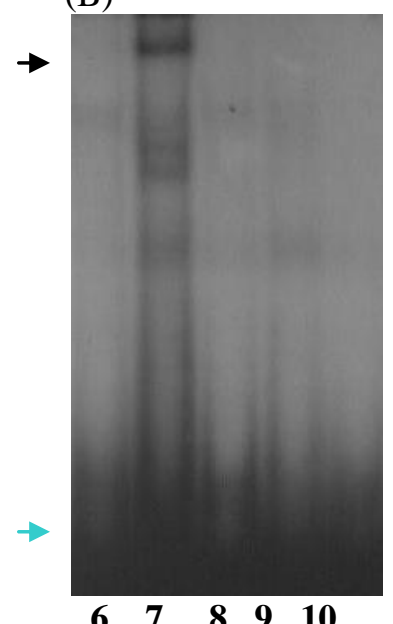

Figure 7. EMSA using primary granulosa $(A)$ and $S K-11(B)$ cell nuclear extracts. The specific DNA-protein complex was detected in-29-poly-probe with strong signals (lane 2 and 7) that could not be detected in-29-wt-probe (lane 1 and 6 ). The bands were competed away by the excess of unlabelled oligonucleotides (lane 4 and 9). Lane 5 and 10 are negative control. Blue arrow indicated the free probes. 


\section{DISCUSSION}

Study of Perez-Mayorga et al. ${ }^{4}$ showed that polymorphisms within exon 10 of FSHR significantly influence the sensitivity of receptor to FSH. It was indicated by the significantly different levels of FSH basal among genotypes according to polymorphism at codon 680. The homozygous Ser/Ser have higher FSH levels than homozygous Asn/Asn. In accordance with FSH levels, homozygous Ser/Ser needed higher FSH ampoules than homozygous Asn/Asn for controlled ovary stimulation (COS). The similar results also achieved by researchers in more recent studies. Studies in the larger samples of Japanese women by Sudo et $a l^{5}$ showed that FSH basal level and the requirement of exogenous FSH of homozygous Ser/Ser women were significantly higher than heterozygous Asn/Ser women. The other interesting result showed by Behre et al. ${ }^{11}$ The peak estradiol levels before hCG administration were significantly lower in homozygous Ser/Ser women compared to Asn/Asn women. The increasing of FSH stimulation dose could overcome the lower estradiol response in women with the Ser/Ser FSHR variant.

From the studies above, it was clear that amino acid exchange in the FSHR protein, caused by SNPs, altered the sensitivity of FSHR to FSH. There are some hypothesis of the molecular mechanisms that could explain the different sensitivity of FSHR among their isoforms, including a different potential for glycosylation and phosphorylation of FSHR isoforms, differences of expression in cell surface of FSHR variants, differential turnover or down-regulation of FSHR isoforms, and differences in affinity to FSH hormone. ${ }^{4}$ However, further research is needed to clarify these hypotheses.

In this study for the first time we reported that in addition to structural gene polymorphism, the core promoter of human FSHR is also polymorphic. We found five SNPs in the core promoter of German women at positions $-29,-37,-114,-123$ and -138 beside the variety of adenine (A) base number in the core promoter of FSHR. The highest frequency of polymorphism detected at position -29 with the allele distributions: $7.25 \%$ for homozygous AA, $30.92 \%$ for heterozygous AG and $61.83 \%$ for homozygous GG, whereas the other four SNPs were found in low frequencies.

With regard to polymorphism of FSHR gene promoter, our functional study showed that position of poly- morphisms in the core promoter of FSHR have great impact to the promoter activities. Polymorphism at position -123 significantly decreased the promoter activities in all three cell lines. This result coincided with EMSA. Our experiment using wt- or poly -123 probes incubated with primary granulosa, JC-410 and SK-11 cell nuclear extracts exhibited a strong band in the wt probe-protein complex. Nucleotide at position -123 belong to $\mathrm{E}$ box sequence $(-124$ to -119$)$ that needed for full promoter activity. ${ }^{8-10,12-13}$ Study on rat FSHR promoter showed that block-replacement mutation on E-box element decreased the promoter activity to the lowest level. ${ }^{13}$ Furthermore, upstream stimulatory factor (USF) 1 and 2 transcription factors identified bind to the $\mathrm{E}$ box sequence. ${ }^{9}$ Based on these facts we suggested that polymorphism at position 123 of $\mathrm{E}$ box element changed the DNA conformation and thereby decreased the binding capacity of USF1 and USF2 transcription factors to its binding sites. Replacement mutation on the central nucleotide CG of the $\mathrm{E}$ box sequence by Xing and Sairam ${ }^{11}$ exhibited the same features. EMSA showed that the mutated probe was not bound by the nuclear proteins. In addition, the mutated probe failed to compete for the binding to wild type probe, even at 200-fold molar excess.

Polymorphism at position -138 , in our functional study, significantly increased the promoter activity in three different cell lines. We suggest that the region including position -138 is important for promoter activity, and polymorphism at this position seems decrease the binding capacity of inhibitor protein to its specific site. It was confirmed by our EMSA that showed the presence of specific DNA-protein complex when primary granulosa, JC-410 and SK-11 cell nuclear extracts incubated with poly-probe. This band could not be detected in wt-probe, however, instead of it, a slower migration band appeared in acrilamide gel. The importance of region surrounding position -138 is also detected from the DNA sequence that conserved among species, i.e: human, rat, mouse and ovine.

Conclusively, the functional analysis proved that polymorphism of human FSHR promoter at a particular site will be affecting FSHR expression. The effect could become positive or negative effect. It was said the positive effect if the polymorphism increases the FSHR expression, inversely, it was considered as negative effect if the polymorphism decreases the FSHR expression. The increasing of promoter activity lead to promotion of receptor protein production resulting in increasing the receptor density on granulosa 
cell surfaces, while the decreasing of promoter activity will be inversely decreasing the receptor density. The increasing or decreasing receptor density will be correlating with the amount of FSH ampoules or the day duration necessary for ovarian stimulation. In this context, the data indicated that FSHR promoter gene polymorphisms are also worth for the ovarian responsive prediction of FSH stimulation in women undergoing IVF/ ICSI. The type of FSHR promoter variant can be used to predict the accurate dose of FSH in order to achieve the optimal stimulation, beside of polymorphism determination in exon 10 . Nevertheless, from this study we realized that frequencies of FSHR promoter gene polymorphisms were low, except for the polymorphism at position -29 .

\section{Acknowledgment}

We thank to Lisa Pekel and Nicole Terwort from IRM for their excellent assistance. This study was supported in part by URGE Project Directorate General of Higher Education and German Academic Exchange Service (DAAD).

\section{REFERENCES}

1. Griswold MD, Heckert L, Lindner C. The molecular biology of the FSH receptor. J Steroid Biochem Mol Biol 1995;53:215-8.

2. Simoni M, Gromoll J, Nieschlag E. The folliclestimulating hormone receptor: Biochemistry, molecular biology, physiology, and pathophysiology. Endocr Rev 1997:18:739-73.

3. Simoni M, Gromoll J, Hoppner W, Kamischke A, Krafft $\mathrm{T}$, Nieschlag E, et al. Mutational analysis of the folliclestimulating hormone (FSH) receptor in normal and infertile men: Identification and characterization of two discrete FSH receptor isoform. J Clin Endocrinol Metab 1999;84:751-5.
4. Mayorga MP, Gromoll J, Behre HM, Gassner C, Nieschlag E, Simoni M. Ovarian response to folliclestimulating hormone (FSH) stimulation depends on the FSH receptor genotype. J Clin Endocrinol Metab 2000;85:3365-9.

5. Sudo S, Kudo M, Wada S, Sato O, Hsueh AJ, Fujimoto S. Genetic and functional analysis of polymorphisms in the human FSH receptor gene. Mol Hum Reprod 2002; 8: 893-9.

6. de Castro F, Ruiz R, Montoro L, Perez-Hernandez D, Sanche Z, Cases Padilla E, Real LM, Ruiz A. Role of follicle-stimulating hormone receptor Ser680Asn polymorphism in the efficacy of follicle-stimulating hormone. Fertil Steril 2003; 80: 571-6.

7. Simoni M, Nieschlag E, Gromoll J. Isoforms and single nucleotide polymorphisms of the FSH receptor gene: implications for human reproduction. Hum Reprod Update 2002; 8:413-21.

8. Gromoll J, Dankbar B, Gudermann T. Characterization of the 5 ' flanking region of the human follicle-stimulating hormone receptor gene. Mol Cell Endocrinol 1994; 102:93-102.

9. Heckert LL, Sawadogo M, Daggett MAF, Chen JC. The USF proteins regulate transcription of the folliclestimulating hormone receptor but are insufficient for cellspecific expression. Mol Endocrinol 2000;14:1836-48.

10. Xing W and Sairam MR. Characterization of regulatory elements of ovine follicle-stimulating hormone (FSH) receptor gene: The role of E-box in the regulation of ovine FSH receptor expression. Biol Reprod 2001;64:579- 89.

11. Behre HM, Greb RR, Mempel A, Sonntag B, Kiesel L, Kalwasser P, Seliger E, Ropke F, Gromoll J, Nieschlag E, Simoni M. Differential estradiol response to FSH stimulation in women depends on FSH receptor polymorphism - a multicenter, prospective, randomized controlled trial. (in press).

12. Goetz TL, Lloyd LT, Griswold MD. Role of E box and initiator region in the expression of the rat folliclestimulating hormone receptor. J Biol Chem 1996; 271:33317-24.

13. Heckert LL, Doggett MAF, Chen JK. Multiple promoter elements contribute to activity of the follicle-stimulating hormone receptor (FSHR) gene in testicular Sertoli cells. Mol Endocrinol 1998;12:1499-512. 